\title{
Propagation of Tau aggregates
}

\author{
Michel Goedert ${ }^{1 *}$ and Maria Grazia Spillantini
}

\begin{abstract}
Since 2009, evidence has accumulated to suggest that Tau aggregates form first in a small number of brain cells, from where they propagate to other regions, resulting in neurodegeneration and disease. Propagation of Tau aggregates is often called prion-like, which refers to the capacity of an assembled protein to induce the same abnormal conformation in a protein of the same kind, initiating a self-amplifying cascade. In addition, prion-like encompasses the release of protein aggregates from brain cells and their uptake by neighbouring cells. In mice, the intracerebral injection of Tau inclusions induced the ordered assembly of monomeric Tau, followed by its spreading to distant brain regions. Short fibrils constituted the major species of seed-competent Tau. The existence of several human Tauopathies with distinct fibril morphologies has led to the suggestion that different molecular conformers (or strains) of aggregated Tau exist.
\end{abstract}

Keywords: Alzheimer's disease, Amyloid, Cell-to-cell spreading, Disease propagation, Prion-like, Protein strains, Tau, Tauopathies

\section{Introduction}

Common human neurodegenerative diseases are characterized by the presence of abundant ordered assemblies with the properties of amyloid fibrils [1,2]. These structures are typically unbranched and $10-20 \mathrm{~nm}$ in diameter; they are composed of $\beta$-strands running perpendicular to the fibre axis and $\beta$-sheets running parallel to the long axis of the fibrils. Each inclusion has a single protein as its major component, with $A \beta$, Tau and $\alpha$-Synuclein being the most commonly involved. These proteins undergo a transformation from a soluble to an insoluble filamentous state, with a number of intermediates. The majority of neurodegenerative diseases is defined by one type of inclusion. Alzheimer's disease (AD), the most prevalent, is characterized by two types of abundant inclusions, $A \beta$ deposits and Tau assemblies.

Most cases of disease are sporadic, but a small percentage is inherited, often in a dominant manner. Inherited cases are caused by mutations in the genes encoding the proteins that make up the inclusions, or proteins that increase their production. Mutations in $M A P T$, the Tau gene, give rise to an inherited form of

\footnotetext{
* Correspondence: mg@mrc-Imb.cam.ac.uk

${ }^{1}$ MRC Laboratory of Molecular Biology, Francis Crick Avenue, Cambridge CB2 $\mathrm{OQH}, \mathrm{UK}$

Full list of author information is available at the end of the article
}

frontotemporal dementia and parkinsonism with abundant filamentous Tau inclusions in brain [3].

From genetic data, it is known that a dysfunction of the amyloid precursor protein (APP) initiates the disease process in familial AD [4]. The same may be true of sporadic AD. However, it is also clear that pathological changes in Tau correlate better with nerve cell dysfunction than $\mathrm{A} \beta$ deposits $[5,6]$. Moreover, a close relationship between tau inclusions and nerve cell loss is well established in hippocampus and cerebral cortex [7]. Furthermore, it remains to be shown how changes in APP can cause neurotoxicity related to Tau aggregation.

For many years, cell autonomous mechanisms were believed to account for human neurodegenerative diseases, implying that the same aggregation events occur in brain cells, independently of neighbouring cells, resulting in degeneration. In post mortem brains, protein inclusions are present in thousands of cells. An alternative view is that the first inclusions form in a small number of cells, from where they propagate to normal cells through non-cell autonomous mechanisms and welldefined pathways depending on the underlying disease, resulting in degeneration.

Propagation of pathology is commonly called "prionlike", referring to the intercellular spreading of protein aggregates. The acronym "prion" stands for "proteinaceous infectious particle", reflecting intercellular 
propagation and interorganismal transmission [8]. There is no evidence to suggest that Tauopathies can transfer between humans, hence the use of "prion-like." Propagation of aggregates requires their release into the extracellular space, uptake by connected cells and seeded aggregation of soluble proteins. Studying the underlying mechanisms may lead to the identification of novel therapeutic targets.

\section{TAU isoforms}

Six Tau isoforms are expressed in adult human brain (Fig. 1a) [9]. They range from 352 to 441 amino acids and are produced by alternative mRNA splicing of transcripts from $M A P T$. The six isoforms are natively unfolded and differ by the presence or absence of inserts of 29 or 58 amino acids in the amino-terminal half, and the inclusion or not, of the 31 amino acid repeat encoded by exon 10 of $M A P T$ in the carboxy-terminal half. Inclusion of exon 10 results in the production of three Tau isoforms with four repeats each (4R), and its exclusion in a further three isoforms with three repeats each (3R). Big Tau, which carries an additional large exon in the amino-terminal half, is expressed in the peripheral nervous system [10, 11]. Together with some adjoining sequences, the repeats constitute the microtubule-binding domains of Tau [12].

The dwell time of Tau on individual microtubules is short and not significantly different between isoforms $[13,14]$. Tau promoted microtubule assembly in the processes of differentiated PC12 cells, but it is not clear if it also stabilised microtubules. Its short dwell time on microtubules makes it possible for Tau to interact with

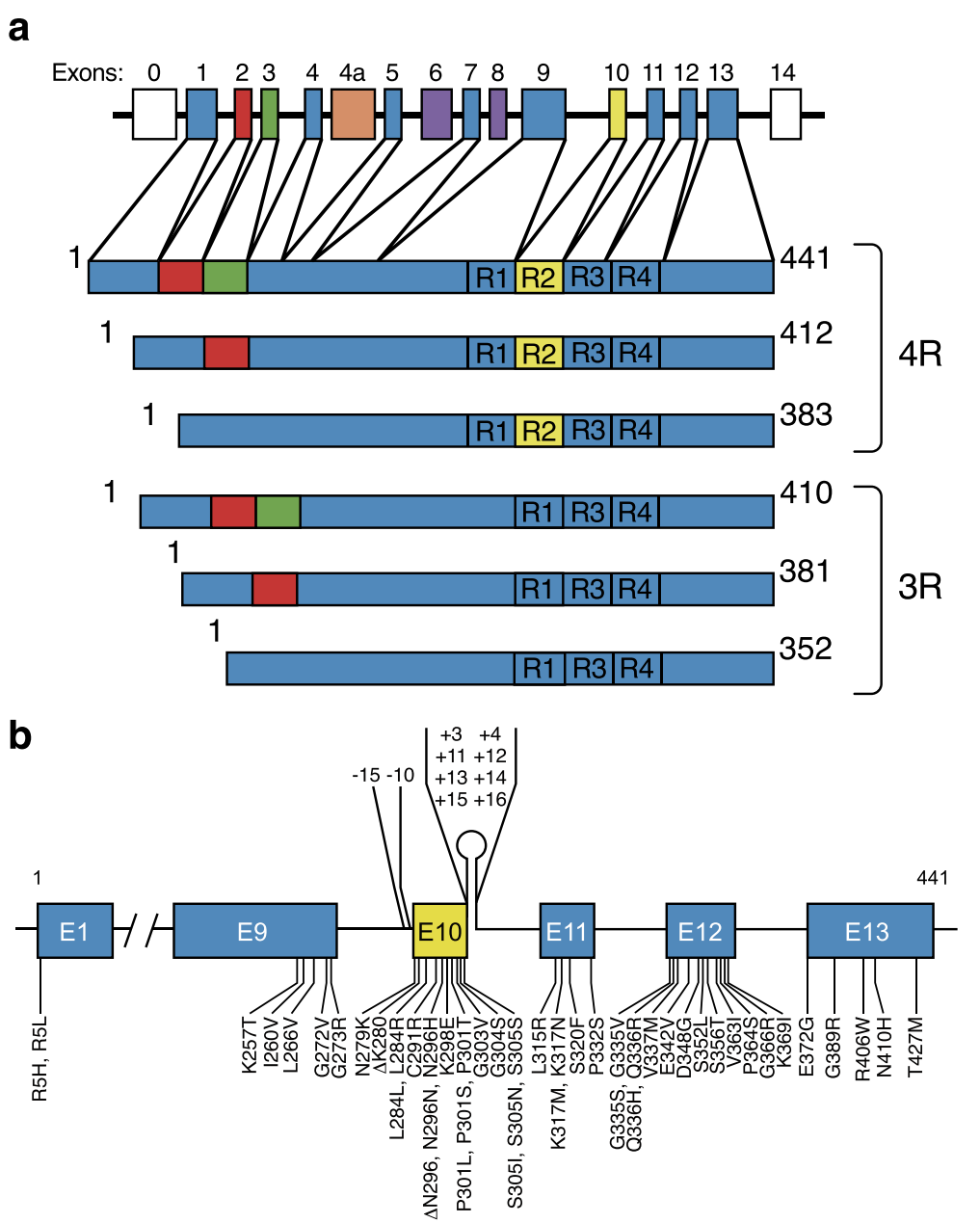

Fig. 1 Human brain Tau isoforms and MAPT mutations. a MAPT and the six Tau isoforms expressed in adult human brain. MAPT consists of 16 exons (E). Alternative mRNA splicing of E2 (red), E3 (green), and E10 (yellow) gives rise to six tau isoforms (amino acids 352-441). Constitutively spliced exons (E1, E4, E5, E7, E9, E11, E12, E13) are shown in blue. E0, which is part of the promoter, and E14 are noncoding (white). E6 and E8 (violet) are not transcribed in human brain. E4a (orange) is only expressed in the peripheral nervous system. The repeats (R1-R4) are shown, with three isoforms having four repeats each (4R) and three isoforms having three repeats each (3R). Each repeat is 31 amino acids in length. Exons and introns are not drawn to scale. $\mathbf{b}$ Mutations in MAPT in cases of frontotemporal dementia and parkinsonism linked to chromosome 17 (FTDP-17 T); 49 coding region mutations and 10 intronic mutations flanking E10 are shown 
additional molecules, such as actin and protein phosphatase 2A. In brain, Tau is subject to a number of posttranslational modifications, including phosphorylation, acetylation, methylation, glycation, isomerisation, OGlcNAcylation, nitration, sumoylation, ubiquitination and truncation [15].

Similar amounts of $3 \mathrm{R}$ and $4 \mathrm{R}$ Tau are expressed in the cerebral cortex of adults [16]. In developing human brain, only the shortest Tau isoform is present. $3 R, 4 R$ and $5 R$ Tau isoforms are found in the brains of adult chickens [17], whereas most adult rodents express only $4 \mathrm{R}$ Tau. What is conserved between species is the expression of one hyperphosphorylated $3 R$ Tau isoform lacking amino-terminal inserts during vertebrate development. Similar repeats are present in the high-molecular weight proteins MAP2 and MAP4 $[18,19]$. It has been suggested that MAP4 derives from a non-vertebrate ancestor, whereas MAP2 and Tau may have shared a more recent common ancestor [20]. The genomes of Caenorhabditis elegans and Drosophila melanogaster each encode one protein with Tau-like repeats [21, 22].

\section{TAU assembly}

Full-length Tau assembles into filaments through some of its repeats and adjoining sequences, with the aminoterminal half and most the carboxy-terminus forming the fuzzy coat [23-27]. Tau filaments from AD brain and those assembled from expressed protein have a cross- $\beta$ structure characteristic of amyloid fibrils [28], with their cores consisting of approximately 90 amino acids. The core of Tau filaments overlaps with part of the region that binds to microtubules, implying that pathological assembly and physiological function are mutually exclusive.

Phosphorylation of Tau negatively regulates its ability to interact with microtubules and filamentous Tau is abnormally hyperphosphorylated [29]. It remains to be seen if phosphorylation is a trigger for aggregation. Many publications equate Tau phosphorylation with aggregation. This may not be correct. It has for instance been shown that highly phosphorylated Tau forms in a reversible fashion during hibernation [30].

In $\mathrm{AD}$, chronic traumatic encephalopathy (CTE), postencephalitic parkinsonism and several other Tauopathies, all six isoforms are present in the disease filaments [1]. In $\mathrm{AD}$, filaments are either paired helical or straight, with both types sharing a common structural subunit [31]. In other diseases-such as progressive supranuclear palsy (PSP), corticobasal degeneration (CBD), argyrophilic grain disease (AGD), globular glial Tauopathy (GGT) and agingrelated Tau astrogliopathy (ARTAG)-only isoforms with 4R Tau are found in the filaments [1]. In Pick's disease (PiD), 3R Tau isoforms predominate in the inclusions [1].
Unlike $\mathrm{AD}$, these diseases lack $\mathrm{A} \beta$ deposits. The morphologies of Tau filaments in different diseases vary, even when they are made of the same isoforms.

It has been suggested that patients with AD-type neurofibrillary degeneration restricted to medial temporal lobe and hippocampus, who lack $A \beta$ deposits, suffer from "primary age-related Tauopathy" (PART), a condition that differs from $\mathrm{AD}$ [32]. It has also been proposed that tangle-only dementia (TD), a relatively rare form of dementia, represents a severe form of PART. However, the view that PART is different from $\mathrm{AD}$ has been challenged, because it is clinically and neuropathologically similar to what appear to be the early pathological stages of $\mathrm{AD}$ [33].

The interaction in vitro between unphosphorylated, full-length, recombinant Tau and some negatively charged compounds, such as sulphated glycosaminoglycans, results in filament assembly [34,35]. Filaments are decorated by antibodies directed against the amino-and carboxy-termini of Tau, but not by an antibody directed against the repeats. These findings, which indicate that the repeat region is inaccessible to the antibody, are identical to those obtained in $\mathrm{AD}$ and other human Tauopathies [36]. However, the mechanisms leading to filament formation inside human brain cells in sporadic Tauopathies remain to be identified. Heparin is probably not involved.

Hexapeptide sequences in R2 (amino acids 275-280, VQIINK) and R3 (amino acids 306-311, VQIVYK) are essential for Tau filament assembly [37, 38]. Microcrystals of a peptide comprising residues 306-311 formed steric zippers [39]. In complex with microtubules, these hexapeptide sequences are in a hairpin conformation [40], consistent with the view that microtubule binding and pathological assembly of Tau are mutually exclusive. Residues 310-313 in Tau (YKPV) differ from the equivalent residues in MAP2 (TKKI). When the latter were changed to YKPV, MAP2c also assembled into filaments [41]. The longest human brain Tau isoform (2N4R, 441 amino acids) contains cysteines in R2 (residue 291) and R3 (residue 322). Intra-and intermolecular disulphide bonds may play a role in the assembly of $3 \mathrm{R}$ and $4 \mathrm{R}$ Tau into filaments.

\section{Genetics of MAPT}

The link between Tau dysfunction and neurodegeneration was established through human genetics. In June 1998, mutations in MAPT were reported in a dominantly inherited form of frontotemporal dementia and parkinsonism linked to chromosome 17q21-22 [42-44]. Fifty-nine pathogenic MAPT mutations had been identified by January 2017 (Fig. 1b). Behavioural symptoms are the most common clinical sign. However, language disturbances are sometimes seen, as are signs of parkinsonism 
and motor neuron disease. The ages of onset are variable, but can be as early as in the third decade. MAPT mutations are always associated with abundant Tau inclusions in nerve cells or in both nerve cells and glial cells [3]. By electron microscopy, Tau filament morphologies vary [45].

Mutations in MAPT account for around 5\% of cases of FTD. They are concentrated in exons 9-12 (encoding R1-R4) and the introns flanking exon 10, and can be divided into those with a primary effect at the protein level and those affecting the alternative splicing of Tau premRNA (Fig. 1). Mutations that act at the protein level change or delete single amino acids, reducing the ability of Tau to interact with microtubules. Some mutations also promote the assembly of Tau into filaments. Mutations with a primary effect at the RNA level are intronic or exonic and increase the alternative mRNA splicing of exon 10 of MAPT. This affects the ratio of $3 \mathrm{R}$ to $4 \mathrm{R}$ isoforms, resulting in the relative overproduction of $4 R$ Tau, and its assembly into filaments. In neurons derived from induced pluripotent stem cells of patients with intronic MAPT mutations, 4R Tau was expressed during development, unlike what happens normally [46, 47].

Aggregated Tau can show different isoform patterns, depending on the MAPT mutations [48]. Mutations $\mathrm{V} 337 \mathrm{M}$ in exon 12 and R406W in exon 13 give rise to insoluble Tau bands of 60,64 and $68 \mathrm{kDa}$ and a weaker band of $72 \mathrm{kDa}$. Following dephosphorylation, six bands are present that align with recombinant Tau, like what is seen in AD. The brains of many individuals with MAPT mutations in exons 9-13 (K257T, L266V, $\Delta K 280$, S305N, G272V, L315R, S320F, S320Y, P332S, Q336H, Q336R, K369I, E372G and G389R) are characterized by abundant Pick bodies made predominantly of 3R Tau. As in sporadic PiD, insoluble Tau shows strong bands of 60 and $64 \mathrm{kDa}$. However, in most cases, variable amounts of the 68 and $72 \mathrm{kDa}$ bands are also observed. A third pattern is characteristic of MAPT mutations that affect the alternative mRNA splicing of exon 10 (intronic mutations and exonic mutations N279K, L284L, L284R, $\Delta$ N296, N296D, N296H, N296N, S305I, S305N and S305S). Insoluble Tau runs as two strong bands of 64 and $68 \mathrm{kDa}$ and a weaker band of $72 \mathrm{kDa}$; following dephosphorylation, three bands are present that align with recombinant 4R Tau (isoforms of 383, 412 and 441 amino acids). A similar pattern of pathological Tau bands is observed for mutations in exon 10, such as P301L, which have their primary effects at the protein level. Aggregation of $4 \mathrm{R}$ Tau has also been described for mutations I260V in exon 9, K317N in exon 11, E342V in exon 12 and $\mathrm{N} 410 \mathrm{H}$ in exon 13, showing that it is possible to alter $3 \mathrm{R}$ and $4 \mathrm{R}$ Tau mRNAs through mutations located outside exon 10.

In populations of European descent, MAPT is characterised by two haplotypes resulting from a $900 \mathrm{~kb}$ inversion (H1) or non-inversion (H2) polymorphism [49]. Inheritance of $\mathrm{H} 1$ is a risk factor for PSP, CBD and Parkinson's disease (PD) [48]. This has been confirmed in genome-wide association studies. The association with PD is particularly surprising, since PD is not characterised by the presence of Tau inclusions.

For PSP and CBD, an association has also been found with an allele at the MOBP/SLC25A38 locus, which results in elevated levels of appoptosin, a protein that activates caspase-3, which can cleave Tau [50]. This may result in increased aggregation of $4 \mathrm{R}$ Tau. The association of $\mathrm{H} 1$ with PSP had a higher odds ratio than that between $\mathrm{APOE} \varepsilon 4 / \varepsilon 4$ and $\mathrm{AD}[51]$. APOE $\varepsilon 4$ is the major risk factor allele for late-onset $\mathrm{AD}$ [52]. $\mathrm{H} 2$ is associated with increased expression of exon 3 of MAPT in grey matter, suggesting that inclusion of exon 3 is protective [53]. Reduced expression of $1 \mathrm{~N} 4 \mathrm{R}$ has also been associated with $\mathrm{H} 2$ [54]. Tau isoforms containing exons 2 and 10 promote aggregation, whereas exon 3 -containing isoforms are inhibitory [55].

Even though all six Tau isoforms form paired helical and straight filaments, there are no known mutations in MAPT that give rise to AD. Tau with an A152T substitution has been reported to be a risk factor for $\mathrm{AD}$, as well as for PSP, CBD and unusual Tauopathies ([56-58], but see also [59]).

\section{Propagation of TAU aggregates}

Tau assembly follows a nucleation-elongation mechanism. Experimentally, nucleation can be circumvented by external seeds of preformed Tau filaments. In 2009, prion-like mechanisms were first implicated in Tau pathology (Fig. 2) [60, 61]. Since then, evidence has accumulated to suggest that Tau assemblies, when applied extracellularly, can "seed" the formation of aggregates, followed by their spreading to other cells. Because Tau is an intracellular protein, its propagation requires seeding, as well as aggregate uptake and release. Even though monomeric Tau is taken up by cells, from which it can be released, it is probably not able to seed aggregation. Expressed 4R Tau cannot be seeded when it lacks residues 275-280 and 306-311 [62]. Aggregation inhibitors may thus be able to reduce Tau-induced seeding and spreading.

Uptake of ordered Tau assemblies depends on heparan sulphate proteoglycans at the cell surface and may occur through macropinocytosis, at least in cultured cells [63]. The seeds probably escape from endosomal vesicles and induce the assembly of cytoplasmic Tau. Following assembly, Tau aggregates are released from cells through ill-defined mechanisms. Intracellular Tau could transfer between cells through tunnelling nanotubes. Alternatively, it could be released into the extracellular space, either freely or inside vesicles. Antibodies may be able to 


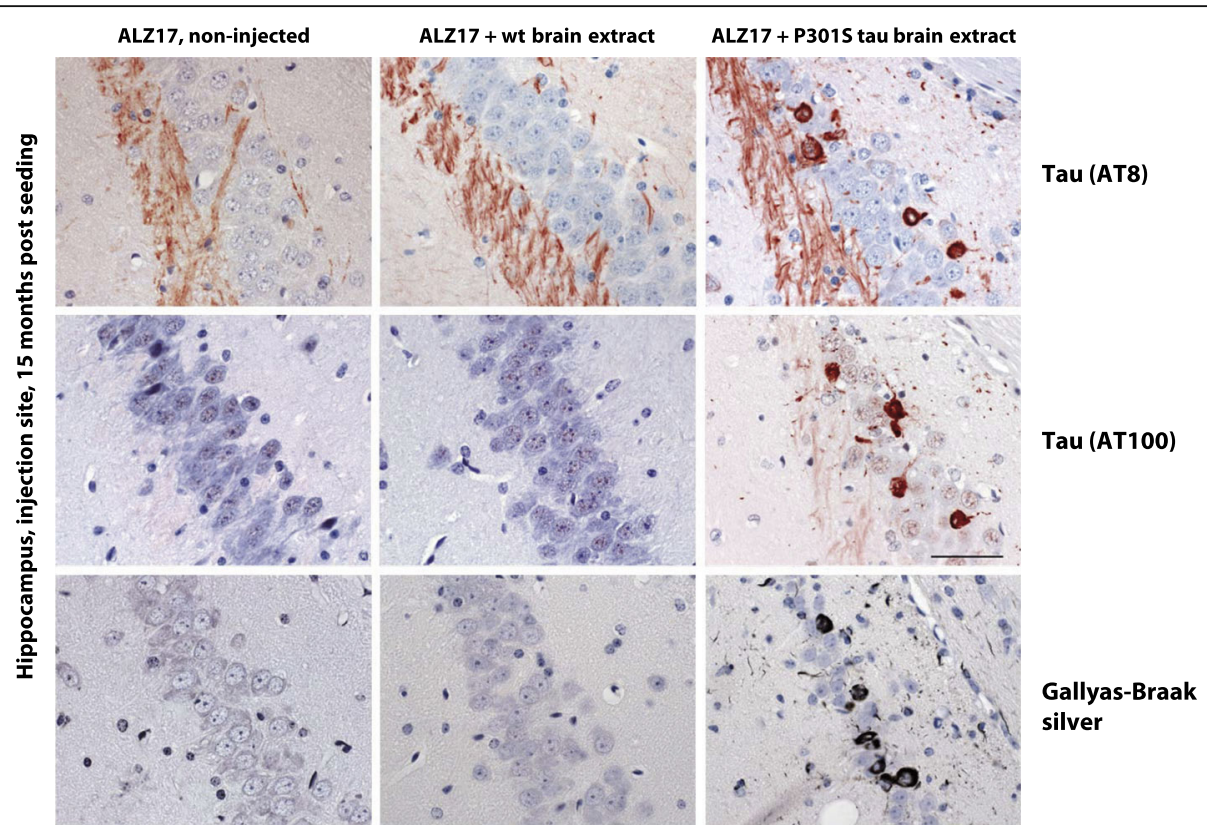

Fig. 2 Induction of filamentous Tau pathology in mice transgenic for wild-type human Tau (line ALZ17) following injection with brain extracts from symptomatic mice transgenic for human mutant P301S tau. Staining of the hippocampal CA3 region of 18-month-old ALZ17 mice with anti-Tau antibodies AT8 and AT100 and Gallyas-Braak silver. Non-injected (left), 15 months after injection of brain extract from non-transgenic control mice (middle) and 15 months after injection with brain extract from 6-month-old mice transgenic for human P301S Tau (right). The sections were counterstained with haematoxylin. Scale bar $=50 \mu \mathrm{m}$

target extracellular Tau aggregates, provided they are not transported in vesicles. Passive immunisation with anti-Tau antibodies has been shown to reduce the amounts of aggregated, hyperphosphorylated Tau in transgenic mice [64-66]. Similarly, antisense oligonucleotides reduced Tau pathology [67]. The aggregation of Tau is known to be concentration-dependent. Tau assemblies can enter cells, where they are detected and neutralised via a danger response mediated by bound anti-Tau antibodies and the cytosolic Fc receptor tripartite motif protein 21 (TRIM21) [68].

Microglial cells have been reported to promote Tau propagation through exosome-dependent mechanisms [69]. A separate study concluded that Tau was released from cells through an exosome-independent pathway that required heat shock cognate 70 , its co-chaperone DnaJ and synaptosomal-associated protein 23 [70]. This work probably described the release of aggregation-incompetent soluble tau. By contrast, optogenetic and chemogenetic approaches have shown that an increase in neural activity can accelerate Tauopathy in transgenic mice [71].

Tau seeds do not need to be phosphorylated, even though seeded Tau aggregates are hyperphosphorylated [62]. Tau assemblies may grow by incorporating unphosphorylated Tau which then undergoes a conformational change and becomes hyperphosphorylated. It remains to be seen if phosphorylation of Tau can influence seeded aggregation.
The intracerebral injection of brain extracts from mice expressing human P301S Tau with inclusions into mice transgenic for wild-type human Tau lacking inclusions (line ALZ17) induced the assembly of wildtype Tau into filaments and its spreading to distant brain regions [60]. No inclusions formed when Tau was depleted from the extracts prior to injection. Aggregated recombinant human Tau also induced inclusion formation, but with a lower efficiency than aggregated Tau from transgenic mouse brain [72, 73]. Similar differences have been described for prions, $\mathrm{A} \beta, \alpha$-synuclein and reactive serum amyloid A assemblies. Recombinant Tau aggregates were more resistant to disaggregation by guanidine hydrochloride and digestion by proteinase $\mathrm{K}$ than Tau aggregates from transgenic mouse brain, consistent with the view that more stable aggregates possess lower seeding activity [62].

Distinct conformations of assembled Tau accounted for differences in seeding potency. Tau filaments formed from recombinant P301S Tau following seeding with aggregated Tau from transgenic mouse brain (in the absence of heparin) showed resistance to guanidine hydrochloride, which was similar to that of Tau seeds from the brains of mice transgenic for human P301S Tau. The seeding potency of Tau filaments was like that of brain-derived aggregated Tau. 
When presymptomatic P301S Tau transgenic mice were injected intracerebrally with brain extracts from symptomatic animals, Tau inclusions formed rapidly at the injection sites [74]. Contralateral and caudo-rostral propagation was evident in nuclei with strong afferent and efferent connections to the injection sites, indicating that the spread of pathology was dependent on connectivity, not proximity.

The intraperitoneal injection of brain extracts from symptomatic P301S Tau transgenic mice into presymptomatic mice promoted the formation of cerebral Tau inclusions [75]. Aggregated Tau can thus promote inclusion formation in the central nervous system of transgenic mice following peripheral administration. Similar findings have been reported for prions, assembled $A \beta$ and assembled $\alpha$-synuclein.

We dissected the molecular characteristics of seedcompetent Tau from the brains of symptomatic P301S Tau transgenic mice (Fig. 3) [76]. Sucrose gradient fractions caused aggregation in transfected cells only when large Tau aggregates ( $>10$ mers) were present. The same fractions induced the formation and spreading of filamentous Tau in presymptomatic transgenic mice, whereas fractions containing monomers and small Tau aggregates were inactive. By immunoelectron microscopy, seed-competent sucrose gradient fractions contained aggregated Tau species ranging from ring-like structures to small fibrils.

\section{Strains of aggregated TAU}

In 2013, we showed that the intracerebral injection of brain homogenates from humans with pathologically confirmed Tauopathies led to the formation of neuronal and glial Tau inclusions in ALZ17 mice [77]. Inclusions formed after inoculation of brain homogenates from all cases of $\mathrm{AD}, \mathrm{TD}, \mathrm{PiD}, \mathrm{AGD}, \mathrm{PSP}$ and CBD. Brain homogenates from patients with AGD, PSP and CBD produced lesions similar to those of the human disorders. With the exception of PiD (3R), the inclusions of the Tauopathies used were made of either $4 \mathrm{R}$ Tau (AGD, PSP and CBD) or a mixture of $3 \mathrm{R}$ and 4R Tau (AD and TD).

Injection of PSP homogenates into ALZ17 mice gave rise to silver-positive neuronal and glial Tau aggregates; the latter were similar to tufted astrocytes, the hallmark lesion of PSP. The injection of CBD homogenates produced neuronal inclusions and silver-positive structures reminiscent of astrocytic plaques. With AGD homogenates, argyrophilic grains and silver-negative astrocytic Tau inclusions were seen, like in the human disease. With the exception of $\mathrm{PiD}$, Tau inclusions propagated over time to connected brain regions. Similar inclusions, but fewer in number, formed after the intracerebral injection into non-transgenic mice of brain homogenates from human Tauopathies. Similar findings have been reported by others following the injection of $\mathrm{AD}$ brain extracts into wild-type mice [78, 79].

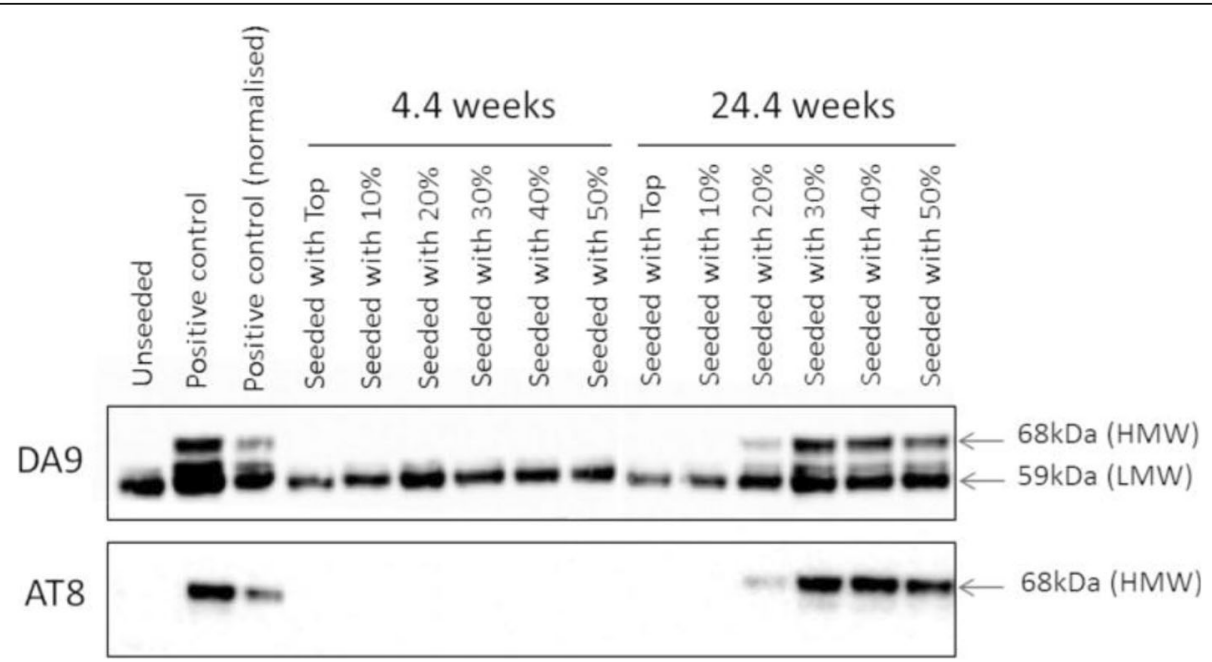

Fig. 3 Seeding of Tau aggregation with sucrose gradient fractions from the brains of mice transgenic for human mutant P301S Tau in a cell-based assay. The mice were aged 4.4 weeks (no symptoms, no Tau filaments) or 24.4 weeks (symptoms, abundant Tau filaments). Sucrose gradient fractions were used to seed aggregation of Tau in HEK cells expressing 1N4R Tau with the P301S mutation. The pellet from a 100,000 g spin of seeded cells was analysed by Western blotting for total Tau and Tau phosphorylated at S202/T205 (anti-Tau antibodies DA9 and AT8). Filamentous Tau runs at approximately $68 \mathrm{kDa}$ (HMW, high-molecular weight); non-filamentous Tau runs at approximately $59 \mathrm{kDa}$ (LMW, low-molecular weight). The positive control consisted in seeding with sarkosyl-extracted Tau from unfractionated brains of symptomatic transgenic P301S Tau mice and the normalised positive control was seeding with sarkosyl-extracted Tau from symptomatic mice, normalised for total Tau levels relative to those of the sucrose gradient fractions. Seeding ability correlated with the presence of the $64 \mathrm{kDa}$ band in 24.4-week-old mice (20-50\% sucrose gradient fractions). No seeding was observed upon addition of sucrose gradient fractions from the brains of 4.4-week-old mice 
These findings were complemented by studies in HEK293 cells that had been stably transfected with part of 4R Tau (residues 244-372) with mutations P301L and V337M fused to YFP [80]. When exposed to Tau seeds, mutant 4R Tau aggregated. Two Tau strains were isolated, based on distinct inclusion morphologies, as well as different biochemical and structural characteristics. Inoculation of these assemblies into the hippocampus of young mice transgenic for human mutant P301S tau (line PS19) induced Tau pathologies that were stable through serial transmission. When HEK cells expressing mutant 4R Tau were seeded with homogenates from these brains, inclusions formed that were identical to those present initially. In subsequent work, another 18 Tau strains were isolated [81]. It remains to be seen how these strains relate to the molecular conformers of aggregated Tau that are characteristic of human Tauopathies.

Induced Tau pathology propagated serially, when brain homogenates from ALZ17 mice that had received bilateral injections of brain extracts from human P301S Tau transgenic mice 18 months earlier, were injected into 3month-old ALZ17 mice [77]. In a different experiment, homogenates were prepared from the brains of nontransgenic mice that had been injected bilaterally with AGD brain homogenates 18 months earlier. Twelve months after the intracerebral injection of these homogenates into ALZ17 mice, many neuropil threads and Tau aggregates were present at the injection sites.

Overexpression of full-length human wild-type 2N3R tau or mutant P301S tau resulted in seeded aggregation upon exposure to AD seeds [68, 78]. Similar findings were obtained when primary neurons from wild-type mice were treated with Tau filaments from AD brain [79]. Seeded aggregation of mutant 4R Tau (244-372) was also observed upon exposure to CTE, PSP, CBD and AGD brain extracts [82]. However, these findings were at the light microscopic level. The resulting Tau filament morphologies are not known. Different strains of aggregated Tau may well exist, but additional work is required. In particular, it will be important to determine if Tau strains from human brain possess unique structural features.

\section{Conclusion}

The ordered assembly of Tau represents the gain of toxic function that causes human Tauopathies. Downstream of assembly, Tau propagation and neurodegeneration take place. Small Tau fibrils are the major species responsible for propagation. The molecular Tau species responsible for neurodegeneration remain to be identified.
Funding

Not applicable.

Availability of data and supporting materials

Not applicable.

Authors' contributions

Both authors contributed equally to the writing.

\section{Competing interests}

The authors declare that they have no competing interests.

Consent for publication

Not applicable.

Ethics approval and consent to participate

Not applicable.

\section{Publisher's Note}

Springer Nature remains neutral with regard to jurisdictional claims in published maps and institutional affiliations.

\section{Author details}

${ }^{1}$ MRC Laboratory of Molecular Biology, Francis Crick Avenue, Cambridge CB2 OQH, UK. ${ }^{2}$ Department of Clinical Neurosciences, Clifford Allbutt Building, University of Cambridge, Hills Road, Cambridge CB2 OAH, UK.

Received: 3 May 2017 Accepted: 17 May 2017

Published online: 30 May 2017

\section{References}

1. Goedert M. Alzheimer's and Parkinson's diseases: the prion concept in relation to assembled $A \beta$, tau and a-synuclein. Science. 2015;349:1255555.

2. Arendt T, Stieler JT, Holzer M. Tau and tauopathies. Brain Res Bull. 2016;126:238-92.

3. Ghetti B, Oblak AL, Boeve BF, Johnson KA, Dickerson BC, Goedert M. Frontotemporal dementia caused by microtubule-associated protein tau gene (MAPT) mutations: a chameleon for neuropathology and neuroimaging. Neuropathol Appl Neurobiol. 2015;41:24-46.

4. Selkoe DJ, Hardy J. The amyloid hypothesis of Alzheimer's disease at 25 years. EMBO Mol Med. 2016;8:595-608.

5. Wilcock GK, Esiri MM. Plaques, tangles and dementia. A quantitative study. J Neurol Sci. 1982;56:343-56.

6. Nelson PT, Alafuzoff I, Bigio EH, Bouras C, Braak H, Cairns NJ, Castellani RJ, Crain BJ, Davies P, Del Tredici K, Duyckaerts C, Frosch MP, Haroutunian V, Hof PR, Hulette CM, Hyman BT, Iwatsubo T, Jellinger KA, Jicha GA, Kövari E, Kukull WA, Leverenz JB, Love S, Mackenzie IR, Mann DM, Masliah E, McKee AC, Montine TJ, Morris JC, Schneider JA, Sonnen JA, Thal DR, Trojanowski JQ, Troncoso JC, Wisniewski T, Woltjer RL, Beach TG. Correlation of Alzheimer disease neuropathologic changes with cognitive status: a review of the literature. J Neuropathol Exp Neurol. 2012;71:362-81.

7. Bondareff W, Mountjoy CQ, Roth M, Hauser DL. Neurofibrillary degeneration and neuronal loss in Alzheimer's disease. Neurobiol Aging. 1989;10:709-15.

8. Prusiner SB. Novel proteinaceous infectious particles cause scrapie. Science. 1982;216:136-44.

9. Goedert M, Spillantini MG, Jakes R, Rutherford D, Crowther RA. Multiple isoforms of human microtubule-associated protein tau: sequences and localization in neurofibrillary tangles of Alzheimer's disease. Neuron. 1989:3:519-26.

10. Goedert M, Spillantini MG, Crowther RA. Cloning of a big tau microtubuleassociated protein tau characteristic of the peripheral nervous system. Proc Natl Acad Sci U S A. 1992;89:1983-7.

11. Couchie D, Mavilia C, Georgieff IS, Liem RK, Shelanski ML, Nunez J. Primary structure of high molecular weight tau present in the peripheral nervous system. Proc Natl Acad Sci U S A. 1992;89:4378-81.

12. Wang $Y$, Mandelkow E. Tau in physiology and pathology. Nat Rev Neurosci. 2016;17:5-21.

13. Janning $D$, Igaev $M$, Sündermann F, Bruhmann J, Beutel $O$, Heinisch JJ, Bakota L, Piehler J, Junge W, Brandt R. Single-molecule tracking of tau reveals fast kiss-and-hop interaction with microtubules in living neurons. Mol Biol Cell. 2014;25:3541-51. 
14. Niewidok $B$, Igaev $M$, Sündermann $F$, Janning $D$, Bakota $L$, Brandt R. Presence of a carboxy-terminal pseudorepeat and disease-like pseudohyperphosphorylation critically influence tau's interaction with microtubules in axon-like processes. Mol Biol Cell. 2016;27:3537-49.

15. Morris M, Knudsen GM, Maeda S, Trinidad JC, loanoviciu A, Burlingame AL, Mucke L. Tau post-translational modifications in wild-type and human amyloid precursor protein transgenic mice. Nat Neurosci. 2015;18:1183-9.

16. Goedert $M$, Jakes $R$. Expression of separate isoforms of human tau protein: correlation with the tau pattern in brain and effects on tubulin polymerization. EMBO J. 1990;9:4225-30.

17. Yoshida H, Goedert M. Molecular cloning and functional characterization of chicken brain tau: isoforms with up to five tandem repeats. Biochemistry. 2002;41:15203-11.

18. Aizawa H, Emori Y, Murofushi H, Kawasaki H, Sakai H, Suzuki K. Molecular cloning of a ubiquitously distributed microtubule-associated protein with Mr 190,000. J Biol Chem. 1990;265:13849-55

19. Lewis SA, Wang D, Cowan NJ. Microtubule-associated protein MAP2 shares a microtubule binding motif with tau protein. Science. 1988;242:936-9.

20. Sündermann F, Fernandez M-P, Morgan RO. An evolutionary roadmap to the microtubule-associated protein MAP Tau. BMC Genomics. 2016;17:264.

21. Goedert M, Baur CP, Ahringer J, Jakes R, Hasegawa M, Spillantini MG, Smith MJ, Hill F. PTL-1, a microtubule-associated protein with tau-like repeats from the nematode Caenorhabditis elegans. J Cell Sci. 1996;109:2661-72.

22. Heidary G, Fortini ME. Identification and characterization of the Drosophila tau homolog. Mech Dev. 2001;108:171-8.

23. Goedert M, Wischik CM, Crowther RA, Walker JE, Klug A. Cloning and sequencing of the CDNA encoding a core protein of the paired helical filament of Alzheimer disease: identification as the microtubule-associated protein tau. Proc Natl Acad Sci U S A. 1988;85:4051-5.

24. Wischik CM, Novak M, Thogersen HC, Edwards PC, Runswick MJ, Jakes R, Walker JE, Milstein C, Roth M, Klug A. Isolation of a fragment of tau derived from the core of the paired helical filament of Alzheimer disease. Proc Natl Acad Sci U S A. 1988;85:4506-10.

25. Wischik CM, Novak M, Edwards PC, Klug A, Tichelaar W, Crowther RA. Structural characterization of the core of the paired helical filament of Alzheimer disease. Proc Natl Acad Sci U S A. 1988;85:4884-8.

26. Kondo J, Honda T, Mori H, Hamada Y, Miura R, Ogawara M, Ihara Y. The carboxyl third of tau is tightly bound to paired helical filaments. Neuron. 1988;1:827-34

27. Wegmann S, Medalsy ID, Mandelkow E, Müller DJ. The fuzzy coat of pathological human tau fibrils is a two-layered polyelectrolyte brush. Proc Natl Acad Sci U S A. 2013;110:E313-21.

28. Berriman J, Serpell LC, Oberg KA, Fink AL, Goedert M, Crowther RA. Tau filaments from human brain and from in vitro assembly of recombinant proteins show cross-beta structure. Proc Natl Acad Sci U S A. 2003;100:9034-8.

29. Iqbal K, Liu F, Gong CX. Tau and neurodegenerative disease: the story so far. Nat Rev Neurol. 2016;12:15-27.

30. Arendt T, Stieler J, Strijkstra AM, Hut RA, Rüdiger J, Van der Zee EA, Harkany T, Holzer M, Härtig W. Reversible paired helical filament-like phosphorylation of tau is an adaptive process associated with neuronal plasticity in hibernating animals. J Neurosci. 2003;23:6972-81.

31. Crowther RA. Straight and paired helical filaments in Alzheimer disease have a common structural unit. Proc Natl Acad Sci U S A. 1991;88:2288-92.

32. Crary JF, Trojanowski JQ, Schneider JA, Abisambra JF, Abner EL, Alazuloff I, Arnold SE, Attems J, Beach TG, Bigio EH, Cairns NJ, Dickson DW, Gearing M, Grinberg LT, Hof PR, Hyman BT, Jellinger K, Jicha GA, Kovacs GG, Knopman DS, Kofler J, Kukull WA, Mackenzie IR, Masliah E, McKee A, Montine TJ, Murray ME, Neltner JH, Santa-Maria I, Seeley WW, Serrano-Pozo A, Shelanski ML, Stein T, Takao M, Thal DR, Toledo JB, Troncoso JC, Vonsattel JP, White CL, Wisniewski T, Woltier RL, Yamada M, Nelson PT. Primary age-related tauopathy (PART): a common pathology associated with human aging. Acta Neuropathol. 2014; 128:755-66.

33. Duyckaerts C, Braak H, Brion JP, Buée L, Del Tredici K, Goedert M, Halliday G, Neumann M, Spillantini MG, Tolnay M, Uchihara T. PART is part of Alzheimer disease. Acta Neuropathol. 2015;129:749-56.

34. Goedert M, Jakes R, Spillantini MG, Hasegawa M, Smith MJ, Crowther RA. Assembly of microtubule-associated protein tau into Alzheimerlike filaments induced by sulphated glycosaminoglycans. Nature. 1996;383:550-3.
35. Pérez M, Valpuesta JM, Medina M, De Garcini EM, Avila J. Polymerization of tau into filaments in the presence of heparin: the minimal sequence required for tau-tau interaction. J Neurochem. 1996;67:1183-90.

36. Goedert M, Spillantini MG, Cairns NJ, Crowther RA. Tau proteins of Alzheimer paired helical filaments: abnormal phosphorylation of all six brain isoforms. Neuron. 1992;8:159-68.

37. Von Bergen M, Friedhoff P, Biernat J, Heberle J, Mandelkow EM, Mandelkow E. Assembly of tau protein into Alzheimer paired helical filaments depends on a local sequence motif (306-VQIVYK-311) forming beta structure. Proc Natl Acad Sci U S A. 2000;97:5129-34.

38. Von Bergen M, Barghorn S, Li L, Marx A, Biernat J, Mandelkow EM, Mandelkow E. Mutations of tau protein in frontotemporal dementia promote aggregation of paired helical filaments by enhancing local beta structure. J Biol Chem. 2001;276:48165-74.

39. Sawaya MR, Sambashivan S, Nelson R, Ivanova MI, Sievers SA, Apostol MI, Thompson MJ, Balbirnie M, Wiltzius JJ, McFarlane HT, Madsen AO, Riekel C, Eisenberg D. Atomic structures of amyloid cross-beta spines reveal varied steric zippers. Nature. 2007;447:453-7.

40. Kadavath $\mathrm{H}$, Jaremko $\mathrm{M}$, Jaremko $\mathrm{L}$, Biernat J, Mandelkow $\mathrm{E}$, Zweckstetter M. Folding of the tau protein on microtubules. Angew Chem Int Ed. 2015;54:10347-51.

41. Xie C, Soeda Y, Shinzaki Y, In Y, Tomoo K, Ihara Y, Miyasaka T. Identification of key amino acids responsible for the distinct aggregation properties of microtubule-associated protein 2 and tau. J Neurochem. 2015;135:19-26.

42. Poorkaj P, Bird TD, Wijsman E, Nemens E, Garruto RM, Anderson L, Andreadis A, Wiederholt WC, Raskind M, Schellenberg GD. Tau is a candidate gene for chromosome 17 frontotemporal dementia. Ann Neurol. 1998:43:815-25.

43. Hutton M, Lendon CL, Rizzu P, Baker M, Froelich S, Houlden H, PickeringBrown S, Chakraverty S, Isaacs A, Grover A, Hackett J, Adamson J, Lincoln S, Dickson D, Davies P, Petersen RC, Stevens M, de Graaf E, Wauters E, van Baren J, Hillebrand M, Joosse M, Kwon JM, Nowotny P, Che LK, Norton J, Morris JC, Reed LA, Trojanowski JQ, Basun H, Lannfelt L, Neystat M, Fahn S, Dark F, Tannenberg T, Dodd PR, Hayward N, Kwok JBJ, Schofield PR, Andreadis A, Snowden J, Craufurd D, Neary D, Owen F, Oostra BA, Hardy J, Goate A, van Swieten J, Mann D, Lynch T, Heutink P. Association of missense and $5^{\prime}$-splice site mutations in tau with the inherited demenmtia FTDP-17. Nature. 1998;393:702-5.

44. Spillantini MG, Murrell JR, Goedert M, Farlow MR, Klug A, Ghetti B. Mutation in the tau gene in familial multiple system tauopathy with presenile dementia. Proc Natl Acad Sci U S A. 1998:95:7737-41.

45. Crowther RA, Goedert M. Abnormal tau-containing filaments in neurodegenerative diseases. J Struct Biol. 2000;130:271-9.

46. Iovino M, Agathou S, González-Rueda A, Del Castillo-Herrera M, Borroni B, Alberici A, Lynch T, O'Dowd S, Geti I, Gaffney D, Vallier L, Paulsen O, Káradóttir RT, Spillantini MG. Early maturation and distinct tau pathology in induced pluripotent stem cell-derived neurons from patients with MAPT mutations. Brain. 2015;138:3345-59.

47. Sposito T, Preza E, Mahoney CJ, Setó-Salvia N, Ryan NS, Morris HR, Arber C, Devine MJ, Goulden H, Warner TT, Bushell TJ, Zagnoni M, Kunath T, Livesey FJ, Fox NC, Rossor MN, Hardy J, Wray S. Developmental regulation of tau splicing is disrupted in stem cell-derived neurons from frontotemporal dementia patients with the $10+16$ splice-site mutation in MAPT. Hum Mol Genet. 2015;24:5260-9.

48. Goedert M, Eisenberg DS, Crowther RA. Propagation of Tau aggregates and neurodegeneration. Annu Rev Neurosci 2017;40:189-210.

49. Stefansson $H$, Helgason A, Thorleifsson G, Steinthorsdottir V, Masson G, Barnard J, Baker A, Jonasdottir A, Ingason A, Gudnadottir VG, Desnica N, Hicks A, Gylfason A, Gudbjartsson DF, Jonsdottir GM, Sainz J, Agnarsson K, Birgisdottir B, Ghosh S, Olafsdottir A, Cazier JB, Kristjansson K, Frigge ML, Thorgeirsson TE, Gulcher JR, Kong A, Stefansson K. A common inversion under selection in Europeans. Nat Genet. 2005;37:129-37.

50. Zhao Y, Tseng I-C, Heyser CJ, Rockenstein E, Mante M, Adame A, Zheng Q, Huang T, Wang X, Arslan PE, Chakrabarty P, Wu C, Bu G, Mobley WC, Y-w Z, St George-Hyslop P, Masliah E, Fraser PK, Xu H. Appoptosin-mediated caspase cleavage of tau contributes to progressive supranuclear palsy pathogenesis. Neuron. 2015;87:963-75.

51. Höglinger GU, Melhem NM, Dickson DW, Sleiman PM, Wamng LS, Klei L, Rademakers R, de Silva R, Litvan I, Riley DE, van Swieten JC, Heutink P, Wszolek ZK, Uitti RJ, Vandrovcova J, Hurtig HI, Gross RG, Maetzler W, Goldwurm S, Tolosa E, Borroni B, Pastor P, Cantwell LB, Han MR, Dillman A, 
van der Brug MP, Gibbs JR, Cookson MR, Hernandez DG, Singleton AB, Farrer MJ, Yu CE, Golbe LI, Revesz T, Hardy J, Lees AJ, Devlin B, Hakonarson H, Müller $U$, Schellenberg GD. Identification of common variants influencing risk of the tauopathy progressive supranuclear palsy. Nat Genet. 2011;43:699-705.

52. Corder EH, Saunders AM, Strittmatter WJ, Schmechel DE, Gaskell PC, Small GW, Roses AD, Haines JL, Pericak-Vance MA. Gene dose of apolipoprotein E type 4 allele and the risk of Alzheimer's disease in late onset families. Science. 1993;261:921-3.

53. Caffrey TM, Joachim C, Wade-Martins R. Haplotype-specific expression of the N-terminal exon 2 and 3 at the human MAPT locus. Neurobiol Aging. 2008;29:1923-9.

54. Valenca GT, Srivastava GP, Oliveira-Filho J, White CC, Yu L, Schneider JA, Buchman AS, Shulman JM, Bennett DA, Jager PL. The role of MAPT haplotype $\mathrm{H} 2$ and isoform $1 \mathrm{~N} / 4 \mathrm{R}$ in parkinsonism of older adults. PLoS One. 2016;11:e0157452.

55. Zhong Q, Condon EE, Nagaraja HN, Kuret J. Tau isoform composition influences rate and extent of filament formation. J Biol Chem. 2012;287:20711-9.

56. Kovacs GG, Wöhrer A, Ströbel T, Botond G, Attems J, Budka H. Unclassifiable tauopathy associated with an A152T variation in MAPT exon 7. Clin Neuropathol. 2011;30:3-10.

57. Kara E, Ling H, Pittman AM, Shaw $K$, de Silva $R$, Simone R, Holton JL, Warren JD, Rohrer JD, Xiromerisiou G, Lees A, Hardy J, Houlden H, Revesz T. The MAPT p.A152T variant is a risk factor associated with tauopathies with atypical clinical and neuropathological features. Neurobiol Aging. 2012;33:2231.e7-e14.

58. Coppola G, Chinnathambi S, Lee JJ, Dombroski BA, Baker MC, Soto-Ortolazo Al, Lee SE, Klein E, Huang AY, Sears R, Lane JR, Karydas AM, Kenet RO, Biernat J, Wanf L-S, Cotman CW, DeCarli CS, Levey Al, Ringman JM, Mendez MF, Chui HC, Le Ber I, Brice A, Lupton MK, Preza E, Lovestone S, Powell J, Graff-Radford N, Petersen RC, Boeve BF, Lippa CF, Bigio EH, Mackenzie I, Finger E, Kertesz A, Caselli RJ, Gearing M, Juncos JL, Ghetti B, Spina S, Bordelon YM, Tourtelotte WW, Frosch MP, Vonsattel JPG, Zarow C, Beach TG, Albin RL, Lieberman AP, Lee VMY, Trojanowski JQ, Van Deerlin VM, Bird TD, Galasko DR, Masliah E, White CL, Troncoso JC, Hannequin D, Boxer AL, Geschwind MD, Kumar S, Mandelkow EM, Wszolek ZK, Uitti RJ, Dickson DW, Haines JL, Mayeux R, Pericak-Vance MA, Farrer LA, Ross OA, Rademakers R, Schellenberg GD, Miller BL, Mandelkow E, Geschwind DH. Evidence for a role of the rare P.A152T variant in MAPT in increasing the risk for FTDspectrum and Alzheimer's diseases. Hum Mol Genet. 2012;21:3500-12.

59. Pastor P, Moreno F, Clarimón J, Ruiz A, Combarros O, Calero M, López de Munain A, Bullido MJ, de Pancorbo MM, Carro E, Antonell A, Coto E, OrtegaCubero S, Hernandez I, Tárraga L, Boada M, Lleó A, Dois-Icardo O, Kulisevsky J, Vázquez-Hiquera JL, Infante J, Rábano A, Fernández-Blázquez MA, Valenti M, Indakoetxea B, Barandiarán M, Gorostidin A, Frank-Garcia A, Sastre I, Lorenzo E, Pastor MA, Elcoroaristizabal X, Lennarz M, Maier W, Rámirez A, Serrano-Rios M, Lee SE, Sánchez-Juan P. MAPT H1 haplotype is associated with late-onset Alzheimer's disease risk in APOE\&4 noncarriers: results from the Dementia Genetics Spanish Consortium. J Alzheimer's Dis. 2016;49:343-52

60. Clavaguera F, Bolmont T, Crowther RA, Abramowski D, Frank S, Probst A, Fraser G, Stalder AK, Beibel M, Staufenbiel M, Jucker M, Goedert M, Tolnay M. Transmission and spreading of tauopathy in transgenic mouse brain. Nat Cell Biol. 2009;11:909-13.

61. Frost $B$, Jacks RL, Diamond MI. Propagation of tau misfolding from the outside to the inside of a cell. J Biol Chem. 2009;284:12845-52.

62. Falcon B, Cavallini A, Angers R, Glover S, Murray TK, Barnham L, Jackson S, O’Neill MJ, Isaacs AM, Hutton ML, Szekeres PG, Goedert M, Bose S. Conformation determines the seeding potencies of native and recombinant tau aggregates. J Biol Chem. 2015;290:1049-65.

63. Holmes BB, DeVos SL, Kfoury N, Li M, Jacks R, Yanamandra K, Ouidja MO, Brodsky FM, Marasa J, Bagchi DP, Kotzbauer PT, Miller TM, Papy-Garcia D, Diamond MI. Heparan sulphate proteoglycans mediate internalization and propagation of specific proteopathic seeds. Proc Natl Acad Sci U S A. 2013;110:E3138-47.

64. Chai X, Wu S, Murray TK, Kinley R, Cella CV, Sims H, Buckner N, Hanmer J, Davies P, O'Neill MJ, Hutton ML, Citron M. Passive immunization with antitau antibodies in two transgenic models. J Biol Chem. 2011;286:34457-67.

65. Yanamandra K, Kfoury N, Jiang H, Mahan TE, Ma S, Maloney SE, Wozniak DF, Diamond MI, Holtzman DM. Anti-tau antibodies that block tau aggregate seeding in vitro markedly decrease pathology and improve cognition in vivo. Neuron. 2013;80:402-14.
66. Sankaranarayanan S, Barten DM, Vana L, Devidze N, Yang L, Cadelina G, Hoque N, DeCarr L, Keenan S, Lin A, Cao Y, Snyder B, Zhang B, Nitla M, Hirschfeld G, Barrezueta N, Polson C, Wes P, Rangan VS, Cacace A, Albright CF, Meredith J, Trojanowski JQ, Lee VMY, Brunden KR, Ahlijanian M. Passive immunization with phosphor-tau antibodies reduces tau pathology and functional deficits in two distinct mouse tauopathy models. PLoS One. 2015;10:e0l25614.

67. DeVos SL, Miller RL, Schoch KM, Holmes BB, Kebodeaux CS, Wegener AJ, Chen G, Shen T, Tran H, Nichols B, Zanardi TA, Kordasiewicz HB, Swayze EE, Bennett CF, Diamond MI, Miller TM. Tau reduction prevents neuronal loss and reverses pathological tau deposition and seeding in mice with tauopathy. Science Transl Med. 2017;9:eaag0481

68. McEwan WA, Falcon B, Vaysburd M, Clift D, Oblak AL, Ghetti B, Goedert M, James LC. Cytosolic FC receptor TRIM21 inhibits seeded tau aggregation. Proc Natl Acad Sci U S A. 2017;113:E8187-96.

69. Asai H, Ikezu S, Tsunoda S, Medalla M, Luebke J, Haydar T, Wolozin B, Butovsky O, Kügler S, Ikezu T. Depletion of microglia and inhibition of exosome synthesis halt tau propagation. Nat Neurosci. 2015;18:1584-93.

70. Fontaine SN, Zheng D, Sabbagh JJ, Martin MD, Chaput D, Darling A, Trotter $\mathrm{JH}$, Stothert AR, Nordhues BA, Lussier A, Baker J, Shelton L, Kahn M, Blair LJ, Stevens SM, Dickey CA. DnaJ/Hsc70 chaperone complexes control the extracellular release of neurodegenerative-associated proteins. EMBO J. 2016;35:1537-49.

71. Wu JW, Hussaini SA, Bastille IM, Rodriguez GA, Mrejeru A, Rilett K, Sanders DW, Cook C, Fu H, Boonen RA, Herman M, Nahmani E, Emrani S, Figueroa YH, Diamond MI, Clelland CL, Wray S, Duff KE. Neuronal activity enhances tau propagation and tau pathology in vivo. Nat Neurosci. 2016;19:1085-92.

72. Clavaguera F, Lavenir I, Falcon B, Frank S, Goedert M, Tolnay M. "Prion-like" template misfolding in tauopathies. Brain Pathol. 2013;23:342-9.

73. Iba M, Guo JL, McBride JD, Zhang B, Trojanowski JQ, Lee VMY. Synthetic tau fibrils mediate transmission of neurofibrillary tangles in a transgenic mouse model of Alzheimer's-like tauopathy. J Neurosci. 2013;33:1024-37.

74. Ahmed Z, Cooper J, Murray TK, Garn K, McNaughton E, Clarke H, Parhizkar S, Ward MA, Cavallini A, Jackson S, Bose S, Clavaguera F, Tolnay M, Lavenir I, Goedert M, Hutton ML, O'Neill MJ. A novel in vivo model of tau propagation with rapid and progressive neurofibrillary tangle pathology: the pattern of spread is determined by connectivity, not proximity. Acta Neuropathol. 2014;127:667-83.

75. Clavaguera F, Hench J, Lavenir I, Schweighauser G, Frank S, Goedert M, Tolnay M. Peripheral administration of tau aggregates triggers intracerebral tauopathy in transgenic mice. Acta Neuropathol. 2014;127:299-301.

76. Jackson SJ, Kerridge C, Cooper J, Cavallini A, Falcon B, Cella CV, Landi A, Szekeres PG, Murray TK, Ahmed Z, Goedert M, Hutton M, O'Neill MJ, Bose S. Short fibrils constitute the major species of seed-competent tau in the brains of mice transgenic for human P301S tau. J Neurosci. 2016;36:762-72.

77. Clavaguera F, Akatsu H, Fraser G, Crowther RA, Frank S, Hench J, Probst A, Winkler DT, Reichwald J, Staufenbiel M, Ghetti B, Goedert M, Tolnay M. Brain homogenates from human tauopathies induce tau inclusions in mouse brain. Proc Natl Acad Sci U S A. 2013;110:9535-40.

78. Audouard E, Houben S, Masaracchia C, Yilmaz Z, Suain V, Authelet M, De Decker R, Buée L, Boom A, Leroy K, Ando K, Brion JP. High-molecular weight paired helical filaments from Alzheimer brain induces seeding of wild-type mouse tau into an argyrophilic 4R tau pathology in vivo. Am J Pathol. 2016;186:2709-22.

79. Guo JL, Narasimhan S, Changolkar L, He Z, Stieber A, Zhang B, Gathagan RJ, Iba M, McBride JD, Trojanowski JQ, Lee VMY. Unique pathological tau conformers from Alzheimer's brains transmit tau pathology in nontransgenic mice. J Exp Med. 2016;213:2635-54.

80. Sanders DW, Kaufman SK, DeVos SL, Sharma AM, Mirhaba H, Li A, Barker SJ, Foley AC, Thorpe JR, Serpell LC, Miller TM, Grinberg LT, Seeley WW, Diamond MI. Distinct tau prion strains propagate in cells and mice and define different tauopathies. Neuron. 2014;82:1271-88.

81. Kaufman SK, Sanders DW, Thomas TL, Ruchinskas AJ, Vaquer-Alicea J, Sharma AM, Miller TM, Diamond MI. Tau prion strains dictate patterns of cell pathology, progression rate, and regional vulnerability in vivo. Neuron. 2016;92:796-812.

82. Woerman AL, Aoyagi A, Patel S, Kazmi SA, Lobach I, Grinberg LT, McKee AC, Seeley WW, Olson SH, Prusiner SB. Tau prions from Alzheimer's disease and chronic traumatic encephalopathy patients propagate in cultured cells. Proc Natl Acad Sci U S A. 2016;113:E8187-96. 